Journal of Animal and Veterinary Advances 11 (7): 1007-1011, 2012

ISSN: $1680-5593$

(C) Medwell Journals, 2012

\title{
Biochemical Differentiation between Bombina bombina bombina (Linneaus, 1761) and B. b. arifiyensis (Ozeti and Yilmaz, 1987) as Revealed by the Skeletal Muscle Protein Bands
}

\author{
Ufuk Bulbul, Sara Altinkaynak Eroglu, Ali Ihsan Eroglu and Zeynep Mutanoglu Kaya \\ Department of Biology, Faculty of Science, Karadeniz Technical University, 61080 Trabzon, Turkey
}

\begin{abstract}
In this study, skeletal muscle protein bands of the Bombina bombina specimens from five populations inhabiting in Turkish Thrace and Northwestern Anatolia were compared by SDS-PAGE (Sodium Dodecyl Sulphate-Poly Acrylamide Gel Electrophoresis). Totally 54 adult ( 26 females and 28 males) B. bombina specimens were used in SDS-PAGE characterization. B. b. bombina specimens in the Thrace group (Degirmenyeni, Buyukdoluk and Durusu populations) had 26 homologous protein bands whereas $B . b$. arifiyensis specimens in the Northwestern Anatolia group (Arifiye and Karasu) had 28 bands. It was shown that specimens of $B . b$. arifiyensis had two additional and unique bands. The results of the present study show that Thrace and Northwestern Anatolia specimens of the B. bombina populations in Turkey are different according to total number of skeletal muscle protein bands.
\end{abstract}

Key words: Skeletal muscle, Bombina bombina, Thrace, Western Anatolia, protein band, Turkey

\section{INTRODUCTION}

The fire-bellied toad, Bombina bombina (Linnaeus, 1758) shows wide distribution in Eastern, Northern and Central Europe. It is critically endangered in most of its current distribution range and protected by the so-called habitat directive of the European Union (Stuckas and Tiedemann, 2006). It is also found in Northwest Anatolia. $B$. bombina is the only representative of the Bombinatoridae living in Turkey where it is confined to small areas in Turkish Thrace and Northwestern Anatolia (Alpagut-Keskin et al., 2010). Both Thracian and Anatolian populations of $B$. bombina are located as peripheral isolates on the Southeast of the Southern margin of the species' range (Mayr, 1963). Anatolian populations of $B$. bombina which are isolated geographically by the Sea of Marmara have been described as a subspecies, B. bombina arifiyensis (Ozeti and Yilmaz, 1987) by Yilmaz (1984, 1986), Ozeti and Yilmaz (1987) and Baran and Atatur (1998) according to morphological investigations. Additionally, Ozeti and Arikan (1989) reported that B. b. arifiyensis specimens in Adapazari were different from $B . b$. bombina specimens in Edirne according to their some globulin (G1 and G4) fractions. Arikan et al. (2010) adressed a different perspective and they compared the size and counts of various blood cells of $B$. bombina specimens belonged to Anatolian and Thracian populations. Nevertheless, the magnitude and pattern of genetic differentiation of Anatolian B. bombina from the European and Thracian populations have not been shown (Alpagut-Keskin et al., 2010). The European fire-bellied toad species have broad geographical distributions with mutually exclusive ranges. In B. bombina, two closely related groups were delineated by allozyme variants: a Northern one, inhabiting lowlands North of the Carpathian Mountains and a Southern one, distributed along the Danubian plains (Szymura et al., 2000; Stuckas and Tiedemann, 2006; Voros et al., 2006; Hofman et al., 2007). Szymura et al. (2000) which also included an Anatolian sample of this species, attempted to analyze mtDNA variation in fire bellied toads but did not include the Thracian populations. The sample from Anatolia although, geographically distant was found to be more similar to the Northern group than the Southern B. bombina (Szymura et al., 2000). Alpagut-Keskin et al. (2010) used information from 20 allozyme loci to test the hypothesis that geographically isolated Anatolian populations of fire-bellied toad showed genetic differentiation when compared with Thracian populations located on the other side of the Bosporus. They reported that the extent and patterns of genetic divergence indicated that the Anatolian and Thracian populations had probably experienced bottlenecks and incipient speciation might have occurred in Anatolian populations of $B$. bombina. To extend these data showing morphological, serological and allozyme differences

Corresponding Author: Ufuk Bulbul, Department of Biology, Faculty of Science, Karadeniz Technical University, 61080 Trabzon, Turkey 
among the Thracian and Anatolian fire-bellied toads in Turkey by a different perspective, the purpose of the present study is to perform a biochemical comparison on the skeletal muscle proteins of the $B$. b. bombina specimens from three populations (Buyukdolluk, Degirmenyeni and Durusu) with B. b. arifiyensis ones from two populations (Arifiye and Karasu) in Turkey for the first time by SDS-PAGE.

\section{MATERIALS AND METHODS}

Total of 54 adult (26 females and 34 males) $B$. bombina specimens were captured from five populations in Turkey (Table 1) and sampling areas were shown in the Fig. 1. LatLon coordinates of the populations were shown in the Table 2 . In each SDSPAGE experiment, one specimen was used for each population and the experiments were repeated for all specimens in each population. Skeletal muscle protein samples of the frogs obtained by grinding $0.1 \mathrm{~g}$ skeletal

Table 1: Locality names and voucher numbers of the studied specimens

\begin{tabular}{|c|c|c|c|}
\hline Subspecies name & Locality & $\mathrm{n}$ & Voucher number \\
\hline B. b. bombina & Edime (Buyukdolluk) & $10\left(6 \sigma^{x}, 4+\right)$ & TrUfB-01-10 \\
\hline B. b. bombina & Edirne (Degirmenyeni) & $10\left(5 \sigma^{x}, 5 q\right)$ & TrUfB-11-20 \\
\hline B. b. bombina & Istanbul (Durusu) & $11\left(60^{x}, 5\right.$ 우 $)$ & TrUfB-21-31 \\
\hline B. b. arifiyensis & Sakarya (Karasu) & $11\left(50^{x}, 69\right)$ & TrUfB-32-42 \\
\hline B. b. arifiyensis & Sakary a (Arifiye) & $12\left(6 \sigma^{x}, 69\right)$ & TrUfB-43-54 \\
\hline
\end{tabular}

muscles of each specimens in liquid nitrogen and by adding $0.1 \mathrm{~mL}$ of DDW (Double Distilled Water) and $0.2 \mathrm{~mL}$ of $2 \times$ SDS gel-loading buffer ( $100 \mathrm{mM}$ Tris-Base $\mathrm{pH}$ $6.8,4 \%$ SDS electrophoresis grade, $0.2 \%$ bromophenol blue and 20\% glycerol) (Sambrook et al., 1989). The samples were boiled for $2 \mathrm{~min}$ in the $2 \times$ SDS gel-loading buffer to denature the proteins prior to loading the samples onto gels (Lutz et al., 2001). SDS-PAGE 99 programme was used for boiling in a thermal block. The size of the minigels was $8.3 \times 7.3 \mathrm{~cm}$ and the resolving gels were $12 \%(\mathrm{w} / \mathrm{v})$ gradient. The $12 \%$ gradient gels were prepared by putting $3.3 \mathrm{~mL}$ of DDW, $4 \mathrm{~mL}$ of $30 \%$ acrylamide mix, (29.2\% acrylamide and $0.8 \% \mathrm{~N}, \mathrm{~N}^{\prime}-$ methylene-bis-acrylamide) $2.5 \mathrm{~mL}$ of $1.5 \mathrm{M}$ Tris $\mathrm{pH} 8.8$, $0.1 \mathrm{~mL}$ of $10 \% \mathrm{SDS}, 0.1 \mathrm{~mL}$ of $10 \%$ ammonium persulfate and $0.004 \mathrm{~mL}$ of TEMED into a beaker. The $5 \%$ stacking gels were prepared by putting $2.7 \mathrm{~mL}$ of DDW, $0.67 \mathrm{~mL}$ of $30 \%$ acrylamide mix, $0.5 \mathrm{~mL}$ of $1.5 \mathrm{M}$ Tris $\mathrm{pH} 6.8,0.04 \mathrm{~mL}$

Table 2: Names and LatLon coordinates of the studied populations.

\begin{tabular}{llccc}
\hline & & $\mathrm{n}$ & & \\
& & - & & \\
Number & Population name & $0^{*} 0^{*}$ & 우 & LatLon coordinates \\
\hline 1 & Edime (Buyukdolluk) & 6 & 4 & $41^{\circ} 45^{\prime} 50^{\prime} \mathrm{N} 26^{\circ} 35^{\prime} 16^{\prime \prime} \mathrm{E}$ \\
2 & Edirne (Degirmenyeni) & 5 & 5 & $41^{\circ} 4622^{\prime} \mathrm{N} 26^{\circ} 33^{\prime} 81^{\prime \prime} \mathrm{E}$ \\
3 & Istanbul (Durusu) & 6 & 5 & $41^{\circ} 19^{\prime} 06 \mathrm{~N} 28^{\circ} 40^{\prime} 52^{\prime \prime} \mathrm{E}$ \\
4 & Sakarya (Karasu) & 5 & 6 & $41^{\circ} 05^{\prime} 57^{\prime} \mathrm{N} 30^{\circ} 39^{\prime} 13^{\prime \prime} \mathrm{E}$ \\
5 & Sakarya (Arifiye) & 6 & 6 & $40^{\circ} 42^{\prime} 52^{\prime} \mathrm{N} 30^{\circ} 21^{\prime} 44^{\prime \prime} \mathrm{E}$ \\
\hline
\end{tabular}

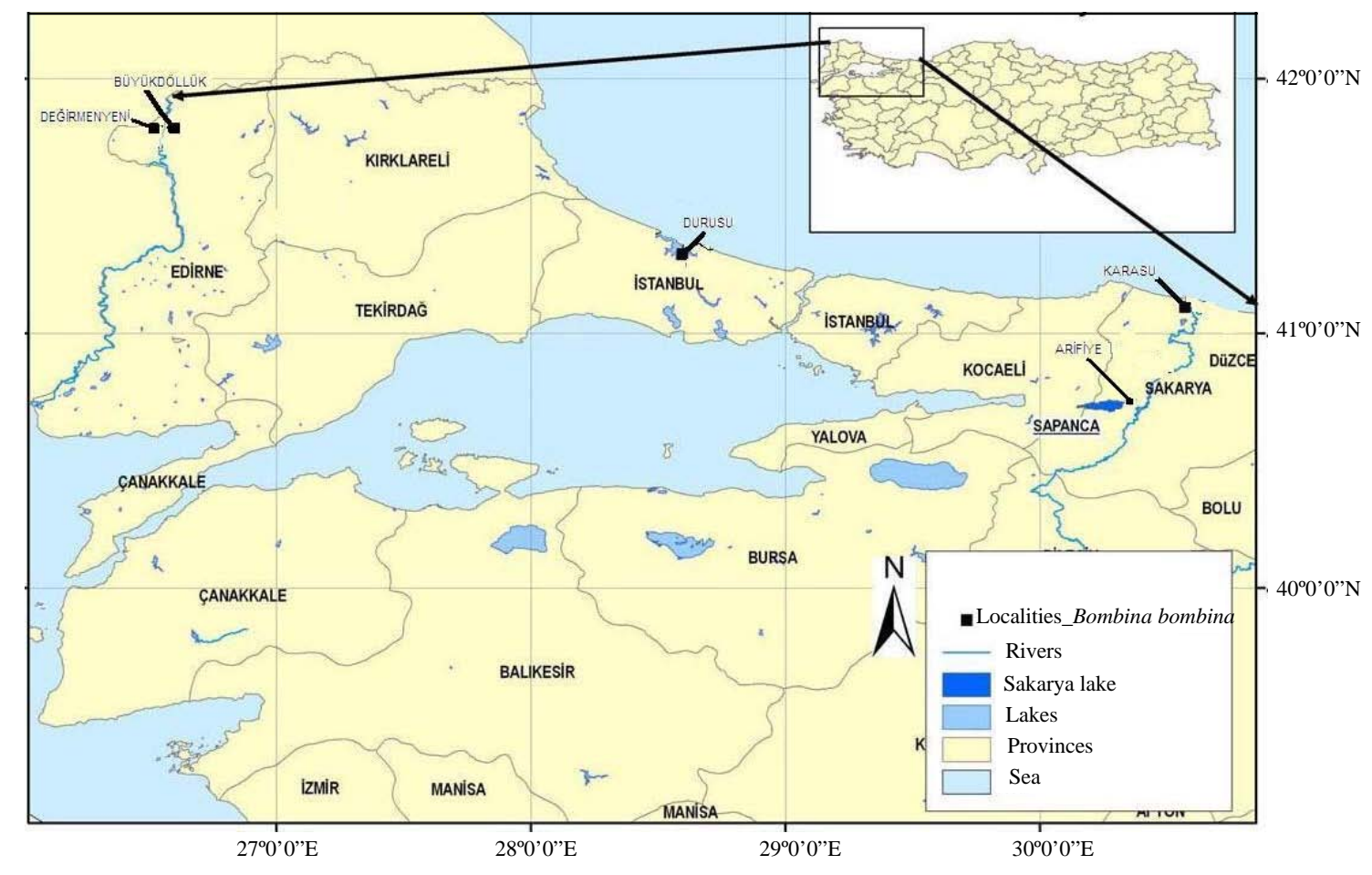

Fig. 1: Map showing the localities of the studied samples 


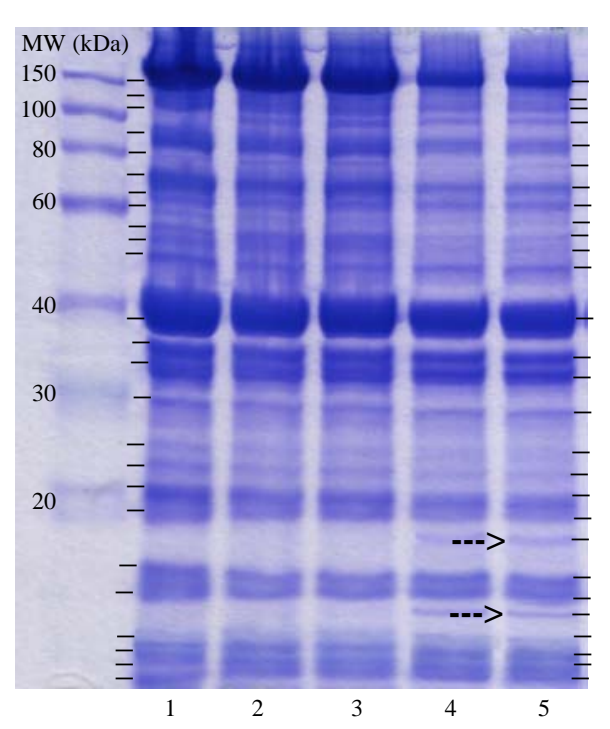

Fig. 2: SDS-PAGE comparison of the five different Bombina bombina specimens from Black sea Region. About $20 \mu \mathrm{L}(36 \mu \mathrm{g})$ of protein samples were applied to the wells. Bars were added upon the best visible protein bands. The two additional and unique bands belonged to the Northwestern Anatolian specimens were shown by the arrow. Numbers from 1-5 represent the names of the populations as followings. 1: Degirmenyeni, 2: Buyukdolluk, 3: Durusu, 4: Arifiye and 5: Karasu

of $10 \% \mathrm{SDS}, 0.04 \mathrm{~mL}$ of ammonium persulfate and $0.004 \mathrm{~mL}$ of TEMED into a beaker (Sambrook et al., 1989). For SDS-PAGE experiments, $1.80 \mu \mathrm{g}$ protein of each $1 \mu \mathrm{L}$ sample was applied to the wells. SERVA recombinant SDS-PAGE protein marker (10-150 KDa Plus, Liquid mix) was used to estimate the positions of the protein bands. Gels were run at a constant current of $20 \mathrm{~mA}$ for $60 \mathrm{~min}$ (Lutz et al., 2001).

Coomassie Brillant Blue (CBB) R-250 was used to stain the gels. The gels were put into the washing solution 1 which was prepared by mixing $50 \mathrm{~mL}$ of methanol, $10 \mathrm{~mL}$ of glacial acetic acid and $40 \mathrm{~mL}$ of DDW for $60 \mathrm{~min}$. Then, the gels were taken to washing solution 2 prepared by $7 \mathrm{~mL}$ of glacial acetic acid, $5 \mathrm{~mL}$ of methanol and $88 \mathrm{~mL}$ of DDW for $60 \mathrm{~min}$. Finally, the gels were scanned in a scanner and they were shown in Fig. 2.

\section{RESULTS AND DISCUSSION}

Skeletal muscle protein bands of three different $B . b$. bombina specimens from Thrace and two different $B . b$. arifiyensis specimens from Northwestern Anatolia populations were compared. Total 26 homologous protein bands were found in Thrace group (Degirmenyeni, Buyukdolluk and Durusu populations) while the Northwestern Anatolia group (Arifiye and Karasu) had 28 bands. The additional 2 protein bands were shown in Fig. 2. Some of the vague bands were not taken into account.

All specimens were used in the SDS-PAGE experiments and it was not found any differences between males and females. The number of skeletal muscle protein bands was always 26 for Thrace group and 28 for Northwestern Anatolia group when researchers used all specimens in different gels. Only the best visible gel is shown in Fig. 2. All these different gels had the same vague bands.

SDS-PAGE results showed that total number of skeletal muscle protein bands was 26 in Thracian group while there were 28 homologous bands in Northwest Anatolian group. Using the total number skeletal muscle protein bands to compare the different amphibian populations was also performed by Bulbul and Kutrup (2007, 2011) and Kutrup and Bulbul (2011).

The results of the study performed by Bulbul and Kutrup (2007) on the total number of protein bands of the green toad (Bufo viridis) showed that Hatay specimens were similar to Kayseri, Rize and Tekirdag specimens while Mersin specimens had 2 different protein bands compared to other specimens in their study.

Bulbul and Kutrup (2011) indicated that the number of skeletal muscle protein bands different in two distinct Turkish marsh frog species (Pelophylax ridibundus and Pelophylax caralitanus). On the other hand, Kutrup and Bulbul (2011) stated that number of skeletal muscle protein bands also could be a good tool to show the biochemical differences between different subspecies.

Based on their SDS-PAGE characterization, the number of the skeletal muscle protein bands was found different between the populations belonged to two different subspecies, Ommatotriton ophryticus ophryticus and O. o. nesterovi of the Northern banded newt, Ommatotriton ophryticus. Similar to these studies on amphibians, Hasnain et al. (2005) studied the soluble muscle proteins in four fish species.

The researchers found that 16 protein bands were diagnostic to Channa gachua and Channa striatus while 10 and 15 bands were to C. marulus and C. punctatus by SDS-PAGE. These data revealed that total number of 
skeletal muscle protein bands and molecular weights of skeletal muscle proteins could be different either among species or subspecies. The results showed that skeletal muscle protein bands were different between Thracian and Northwestern Anatolian samples by SDS-PAGE. Conformably with the SDS-PAGE comparison, Alpagut-Keskin et al. (2010) analyzed 20 allozyme loci from Thracian and Northwestern Anatolian's B. bombina specimens by polyacrylamide gel electrophoresis. They reported that Thracian and Northwestern Anatolian specimens were different.

In parallel, Ozeti and Arikan (1989) reported that B. $b$. arifiyensis specimens in Adapazari were different from $B$. b. bombina specimens in Edirne according to globulin fractions. Arikan et al. (2010) used a different approach and they indicated that Northwestern Anatolian $B$. bombina samples share general features with other anurans but differ from other populations of the same species in blood cell parameters.

In line with electrophoretic studies, Yilmaz (1984, 1986), Ozeti and Yilmaz (1987) and Baran and Atatur (1998) stated that Anatolian populations of $B$. bombina have been described as a subspecies, B. bombina arifiyensis according to morphological investigations.

\section{CONCLUSION}

In this study, differences in the number of skeletal muscle protein bands of the Thracian B. b. bombina samples from three populations (Degirmenyeni, Buyukdolluk and Durusu) and Northwestern Anatolian B. b. arifiyensis specimens from two populations (Arifiye and Karasu) are consistent with the previous morphological and biochemical data.

The study provides additional data on biochemical knowledge of the Bombina bombina specimens in Turkey. Based on the the protein SDS-PAGE results, researchers suggest to follow the common idea proposing that Bombina bombina is subdivided into two geographic fragments: the Thracian group is allocated to the $B . b$. bombina subspecies while Northwestern group is named as $B . b$. arifiyensis.

\section{ACKNOWLEDGEMENTS}

This study was supported financially by the Karadeniz Technical University Scientific Researches Unit (2008.111.004.9). Researchers wish to thank Umut Bulbul and Samet Alboy for their assistances in the field study.

\section{REFERENCES}

Alpagut-Keskin, N., E.I. Cevik and H. Arikan, 2010. Genetic differentation among peripheral populations of Bombina bombina from Thrace and Anatolia: An allozyme analysis. Biochem. Genet., 48: 125-140.

Arikan, H., N. Alpagut-Keskin, I.E. Cevik and U.C. Erismis, 2010. A study on the blood cells of the fire-bellied toad, Bombina bombina L. (Anura: Bombinatoridae). Anim. Biol., 60: 61-68.

Baran, I. and M.K. Atatur, 1998. Turkish herpetofauna (Amphibians and Reptiles). Republic of Turkey, Ministry of Environment, Ankara, pp: 214.

Bulbul, U. and B. Kutrup, 2007. Comparison of skeletal muscle protein bands among five populations of $B u f o$ viridis in Turkey by SDS-PAGE. Turk. J. Zool., 31: 419-422.

Bulbul, U. and B. Kutrup, 2011. A comparison of skeletal muscle protein bands in Pelophylax ridibundus (Pallas, 1771) and Pelophylax caralitanus (Arikan, 1988) populations in Turkey using SDS-PAGE. Turk. J. Zool., 35: 769-775.

Hasnain, A., S.H. Asif, R. Ahmad and R.B. Pandey, 2005. Identification of species-marker bands in native and SDS-PAGE patterns of soluble muscle proteins of four species of genus Channa (Channidae: Channiformes) with evidence of some intraspecies heterogeneity. Asian Fish. Sci., 18: 49-58.

Hofman, S., C. Spolsky, T. Uzzell, D. Cogalniceanu, W. Babiks and J.M. Szymura, 2007. Phylogeography of the fire-bellied toads Bombina: Independent Pleistocene histories inferred from mithocondrial genomes. Mol. Ecol., 16: 2301-2316.

Kutrup, B. and U. Bulbul, 2011. Comparison of skeletal muscle protein bands and trunk vertebrae count between Ommatotriton ophryticus nesterovi and $\mathrm{O}$. ophryticus populations in Turkey. Turk. J. Zool., 35: 579-584.

Lutz, G.J., S.N. Brenner, M.J. Bade and R.L. Lieber, 2001. Identification of myosin light chains in Rana pipiens skelatal muscle and their expression patterns along single fibres. J. Exp. Biol., 204: 4237-4248.

Mayr, E., 1963. Animal Species and Evolution. Harvard University Press, Cambridge, Pages: 797.

Ozeti, N. and H. Arikan, 1989. A preliminary survey on serum proteins of the Turkish populations of Bombina bombina (Anura: Discoglossidae). Istanbul Univ., Fen. Fak. Mec. Ser. B, 51: 13-18.

Ozeti, N. and I. Yilmaz, 1987. On a new form of Bombina bombina (Anura: Discoglossidae) from Northwest Anatolia. J. Fac. Sci., Ege Univ., 9: 41-49. 
Sambrook, J., E.F. Fritsch and T.A. Maniatis, 1989. Molecular Cloning: A Laboratory Manual. 2nd Edn., Cold Spring Harbor Laboratory Press, New York, USA., ISBN-13: 9780879695774 , Pages: 3.

Stuckas, H. and R. Tiedemann, 2006. Eight new microsatellite loci for the critically endangered fire-bellied toad Bombina bombina and their cross-species applicability among anurans. Mol. Ecol. Notes, 6: 150-152.

Szymura, J.M., T. Uzzell and C. Spolsky, 2000. Mitochondrial DNA variation in the hybridizing fire-bellied toads, Bombina bombina and $B$. Variegata. Mol. Ecol., 9: 891-899.
Voros, J., M. Alcobendas, I. Martinez-Solano and M. Garcia-Paris, 2006. Evolution of Bombina bombina and Bombina variegate (Anura: Discoglossidae) in the Carpathian Basin: A history of repeated mt-DNA introgession across species. Mol. Phylogenet. Evol., 38: 705-718.

Yilmaz, I., 1984. A morphological and taxonomical investigation of Thracian anurans. Doga Bilim Dergisi, 8: 244-264.

Yilmaz, I., 1986. On the distribution of the fire-bellied toad Bombina bombina L. in Turkey. Zool. Middle East, 1: 109-110. 